\title{
UTILIZATION OF F-AHP METHOD IN BRI FOR GIVING SELECTION OF KUR
}

\author{
Meiyanto Eko Sulistyo $^{(1)}$, Ristu Saptono ${ }^{(2)}$, Olivia Sari Kusuma Dewi ${ }^{(3)}$ \\ 1) Program Studi Teknik Elektro, Fakultas Teknik \\ Universitas Sebelas Maret, Surakarta \\ ${ }^{2,3)}$ Program Studi Informatika, Fakultas Matematika dan IImu Pengetahuan Alam \\ Universitas Sebelas Maret, Surakarta \\ e-mail: mekosulistyo@staff.uns.ac.id ${ }^{(1)}$, ristu.saptono@staff.uns.ac.id ${ }^{(2)}$, \\ olivia.sari14@gmail.com ${ }^{(3)}$
}

\begin{abstract}
Bank Rakyat Indonesia (BRI) is a business entity which collects funds from the public in the form of deposits and distribute to the public in the form of the People 's Business Credit (KUR) or loan. Along with over time after KUR realized, there is no doubt BRI will be faced with the problems of risk, namely the risk of KUR problematic. There are several methods that can be used in making a decision to be able to solve the problem include the Analytical Hierarchy Process (AHP).AHP is used when the decision involves many factors, where the decision had difficulty in making the weight of each factor. Despite this problem the use of AHP in Multiple Criteria Decision Making (MCDM) approach has less to cope with uncertainties taken by decision-makers, when it should give a definite value in the pairwise comparison matrix therefore, to overcome the weaknesses of the existing AHP then developed a method namely Fuzzy Analytic Hierarchy Process (F-AHP). F-AHP method is the combination between fuzzy AHP approach. The results of research conducted using the Fuzzy Analytic Hierarchy Process (F-AHP) has a $100 \%$ accuracy this is evidenced by the results obtained together with the calculation of banking. Calculation banking mention of 20 customers, acquired 14 accepted and rejected 6.
\end{abstract}

Kata Kunci : BRI, KUR, F-AHP

\begin{abstract}
Abstrak
Bank Rakyat Indonesia (BRI) merupakan badan usaha yang menghimpun dana dari masyarakat dalam bentuk simpanan dan menyalurkan kepada masyarakat dalam bentuk Kredit Usaha Rakyat (KUR) ataupun pinjaman. Seiring dengan berjalannnya waktu sesudah KUR direalisasikan, tidak dapat dipungkiri pihak perbankan akan dihadapkan pada permasalahan risiko, yaitu risiko KUR bermasalah. Ada beberapa metode yang dapat digunakan dalam membuat suatu keputusan untuk dapat memecahkan masalah tersebut diantaranya adalah Analytical Hierarchy Process (AHP). AHP digunakan manakala keputusan yang diambil melibatkan banyak faktor, dimana pengambilan keputusan mengalami kesulitan dalam membuat bobot setiap faktor tersebut. Meskipun demikian penggunaan AHP dalam permasalahan Multi Criteria Decision Making (MCDM) kurang mempunyai pendekatan untuk mengatasi faktor ketidakpastian yang diambil oleh pengambil keputusan, ketika harus memberikan nilai yang pasti dalam matriks perbandingan berpasangan, oleh karena itu, untuk mengatasi kelemahan AHP yang ada makadikembangkan suatu metode yaitu Fuzzy Analytic Hierarchy Process (F-AHP). Metode F- AHP merupakan penggabungan antara metode AHP dengan pendekatan fuzzy. Hasil dari penelitian yang dilakukan menggunakan metode Fuzzy Analytic Hierarchy Process (F-AHP) memiliki keakuratan 100\% hal ini dibuktikan dengan hasil yang diperoleh sama dengan perhitungan pihak perbankan. Perhitungan perbankan menyebutkan dari 20 nasabah, diperoleh 14 diterima dan 6 ditolak.
\end{abstract}

Kata Kunci : BRI, KUR, F-AHP 


\section{PENDAHULUAN}

Bank Rakyat Indonesia (BRI) adalah salah satu bank yang dipercaya oleh pemerintah untuk memberikan fasilitas Kredit Usaha Rakyat (KUR) kepada masyarakat dengan menghimpun dana dari masyarakat dalam bentuk simpanan dan menyalurkan kepada masyarakat dalam bentuk kredit ataupun pinjaman. Seiring dengan berjalannnya waktu sesudah kredit direalisasikan, tidak dapat dipungkiri pihak perbankan akan dihadapkan pada permasalahan risiko, yaitu risiko kredit bermasalah (Pato, 2013). Peranan pihak perbankan sangatlah penting untuk menunjang kelancaran kredit yang merupakan salah satu unsur penting untuk kegiatan dan perkembangan perekonomian di indonesia. Walaupun kredit tersebut mempunyai risiko, pemberian kredit diselenggarakan oleh pihak perbankan karena adanya kebutuhan yang timbul oleh perkembangan ekonomi dan kebutuhan manusia.

AHP dikembangkan di Wharton Scholl of Business oleh Thomas L. Saaty pada tahun 1970an (Saaty \& Vegas, 1991). AHP merupakan proses dalam pengambilan keputusan dengan menggunakan perbandingan berpasangan (Pairwise Comparisons) untuk menjelaskan faktor evaluasi dan faktor bobot dalam kondisi multi faktor. Meskipun demikian penggunaan AHP dalam permasalahan Multi Criteria Decision Making (MCDM) sering dikeritisi sehubungan dengan kurang mampunya pendekatan AHP untuk mengatasi faktor ketidakpastian yang diambil oleh pengambil keputusan ketika harus memberikan nilai yang pasti dalam matriks perbandingan berpasangan dalam mengatasi kelemahan AHP yang ada maka dikembangkan suatu metode yang disebut F- AHP merupakan penggabungan antara metode AHP dengan pendekatan fuzzy. Hakekatnya Fuzzy Analytic Hierarchy Process (FAHP) merupakan penilaian (preferensi) pengambil keputusan yang mengandung sifat uncertainty ini dimodelkan dengan menggunakan logika fuzzy. Informasi dalam Fuzzy Analytic Hierarchy Process (FAHP) seperti halnya dengan Analytic Hierarchy Process (AHP) konvensional diperoleh dalam bentuk matriks perbandingan berpasangan. Skala yang digunakan mulai dari sama penting sampai mutlak lebih penting. Skala dalam bentuk variabel linguistik tersebut dalam Analytic Hierarchy Process (AHP) konvensional yang dilakukan oleh Saaty bernilai 1-9, dikonversikan dalam bentuk fuzzy menggunakan Triangular Fuzzy Number (TFN) (Saaty \& Vegas, 1991). Dalam penentuan bobot elemen-elemen digunakan operasi aritmetik untuk Triangular Fuzzy Number (TFN). Dengan demikian tujuan dari sistem ini adalah untuk memanfaatkan kinerja pembuat keputusan.

\section{LANDASAN TEORI}

\subsection{Kredit}

Kredit berasal dari kata credere yang artinya adalah kepercayaan, maksudnya adalah apabila seseorang memperoleh kredit maka berarti mereka memperoleh kepercayaan. Sementara itu, bagi si pemberi kredit artinya memberikan kepercayaan kepada seseorang bahwa uang yang dipinjamkan pasti kembali (Pato, 2013).

\subsubsection{Unsur-Unsur Kredit}

Unsur-unsur yang terdapat dalam pemberian kredit adalah (Pato, 2013):

1. Kepercayaan. Kepercayaan merupakan suatu keyakinan bagi kreditur bahwa kredit yang diberikan (baik berupa uang, jasa atau barang) akan benar-benar diterimanya kembali dimasa yang akan datang sesuai jangka waktu kredit.

2. Kesepakatan. Disamping unsur percaya didalam kredit juga mengandung unsure kesepakatan antara kreditur dengan debitur. Kesepakatan ini dituangkan dalam suatu perjanjian dimana masing-masing pihak menandatangani hak dan kewajibannya masingmasing.

3. Jangka waktu. Setiap kredit yang diberikan memiliki jangka waktu tertentu, jangka waktu ini mencakup masa pengembalian kredit yang telah disepakati. Jangka waktu tersebut bias berbentuk jangka pendek (dibawah 1 tahun), jangka menengah (1 sampai 3 tahun) dan jangka panjang (diatas 3 tahun). Jangka waktu merupakan batas waktu pengembalian angsuran kredit yang sudah disepakati kedua belah pihak.

4. Risiko. Akibat adanya tenggang waktu, maka pengembalian kredit akan memungkinkan suatu risiko tidak tertagihnya atau macet pemberian suatu kredit. Semakin panjang suatu jangka waktu kredit, maka semakin besar risikonya, demikian pula sebaliknya. 
5. Balas jasa. Balas jasa bagi bank merupakan keuntungan atau pendapatan atas pemberian suatu kredit. Balas jasa kita kenal dengan nama bunga. Disamping balas jasa dalam bentuk bunga bank juga membebankan kepada nasabah biaya administrasi kredit yang juga merupakan keuntungan bagi bank.

\subsubsection{Prinsip-Prinsip Pemberian Kredit}

Menurut Pato ada beberapa prinsip - prinsip penilaian kredit yang sering dilakukan yaitu dengan analisis 5 C. Analisis $5 \mathrm{C}$ adalah sebagai berikut (Pato, 2013):

1. Character. Pengertian character adalah sifat atau watak seseorang dalam hal ini calon nasabah. Tujuannya adalah untuk memberikan keyakinan kepada bank bahwa,sifat atau watak dari orang-orang yang akan di berikan kredit benar - benar dapat dipercaya.

2. Capacity. Melihat kemampuan calon nasabah dalam membayar kredit yang dihubungkan dengan kemampuannya mengelola bisnis serta kemampuanya mencari laba. Sehingga pada akhirnya akan terlihat kemampuannya dalam mengembalikan kredit yang disalurkan.Semakin banyak sumber pendapatan seseorang maka semakin besar kemampuanya untuk membayar kredit.

3. Capital. Biasanya bank tidak akan bersedia untuk membiayai suatu usaha $100 \%$, artinya setiap debitur yang mengajukan permohonan kredit harus pula menyediakan dana dari sumber lainnya atau modal sendiri dengan kata lain Capital adalah untuk mengetahui sumber-sumber pembiayaan yang dimilki debitur terhadap usaha yang akan dibiayai oleh bank.

4. Collateral. Jaminan yang diberikan calon nasabah baik yang bersifat fisik maupun nonfisik. Jaminan hendaknya melebihi jumlah kredit yang diberikan. Jaminan juga harus diteliti keabsahannya, sehingga jika terjadi suatu masalah, maka jaminan yang dititipkan akan dapat dipergunakan secepat mungkin. Fungsi jaminan adalah sebagai pelindung bank dari risiko kerugian.

5. Condition of Economy. Menilai kredit hendaknya juga dinilai kondisi ekonomi sekarang dan untuk di masa yang akan datang sesuai sektor masing-masing. Dalam kondisi perekonomian yang kurang stabil sebaiknya pemberian kredit untuk sektor tertentu jangan diberikan terlebih dahulu dan kalaupun jadi diberikan sebaiknya juga dengan melihat prospek usaha tersebut di masa yang akan datang.

\subsection{Logika Fuzzy}

Logika fuzzy merupakan salah satu komponen pembentuk soft computing. Logika fuzzy pertama kali diperkenalkan oleh Prof. Lotfi A. Zadeh pada tahun 1965. Dasar logika fuzzy adalah teori himpunan fuzzy. Pada teori himpunan fuzzy, peranan derajat keanggotaan sebagai penentu keberadaan elemen dalam suatu himpunan sangatlah penting. Nilai keanggotaan atau derajat keanggotaan atau membership function menjadi ciri utama dari penalaran dengan logika fuzzy (Kusumadewi \& Purnomo, 2010).

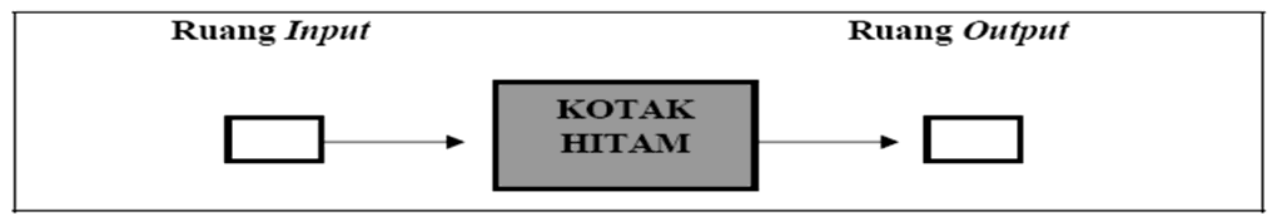

Gambar 1. Pemetaan Input-Output Pada Logika Fuzzy

\subsection{Triangular Fuzzy Number (TFN)}

Triangular Fuzzy Number (TFN) digunakan untuk memutuskan prioritas dari variabel suatu keputusan pada F-AHP. Pendekatan TFN digunakan untuk memilih pilahan dari satu kriteria dari yang lain dan kemudian menggunaakan metode analisis yang lebih luas, menghitung nilai synthetic extent dari perbandingan berpasangan. Berdasarkan pendekatan ini, bobot vektor dapat diputuskan dan dinormalisasi, kemudian bobot vektor yang telah dinormalisasi akan diputuskan. Prioritas terbesar dapat diberikan pada bobot dengan nilai terbesar [9]. Skala 
perbandingan berpasangan pada F-AHP dengan skala perbandingan berpasangan pada AHP. Dimana I, $\mathrm{m}$ dan $\mathrm{u}$, secara berturut-turut menyatakan nilai terendah, nilai tengah dan nilai tertinggi. Parameter I dan u menjelaskan bilangan fuzzy yang menunjukan nilai kemungkinan terkecil dan nilai kemungkinan terbesar. Sedangkan $m$ adalah nilai tengah. Sebuah bilangan segitiga fuzzy digambarkan sebagai berikut (Ozdagoglu \& Ozdagoglu. 2007):

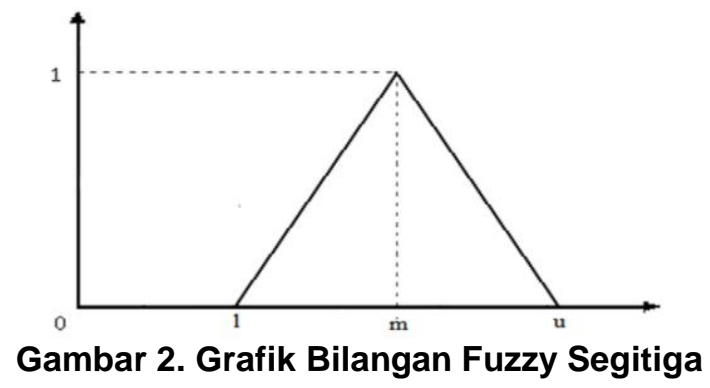

\subsection{AHP}

\subsubsection{Definisi AHP}

Metode Analytic Hierarchy Process (AHP) dikembangkan oleh Thomas L. Saaty, seorang matematikawan di Universitas Pittsburgh Amerika Serikat sekitar tahun 1970. Tujuan utama AHP adalah untuk memilih salah satu yang terbaik bagi kasus multi kriteria yang menggabungkan faktor kualitatif dan kuantitatif di dalam keseluruhan evaluasi alternatifalternatif yang ada. AHP digunakan untuk mengkaji permasalahan yang dimulai dengan mendefinisikan permasalahan tersebut secara seksama kemudian menyusunnya ke dalam suatu hirarki. Proses ini bergantung pada imajinasi, pengalaman, dan pengetahuan untuk menyusun hirarki suatu permasalahan dan bergantung pada logika dan pengalaman untuk memberi pertimbangan (Saaty \& Vegas, 1991).

\subsubsection{Prinsip-Prinsip Dasar AHP}

Menurut Saaty, ada beberapa prinsip yang harus dipahami dalam menyelesaikan permasalahan dengan metode Analytic Hierarchy Process (AHP) meliputi (Saaty 2008):

1. Mendefinisikan masalah dan menentukan solusi yang diinginkan, lalu menyusun hierarki dari permasalahan yang dihadapi.

2. Synthesis of priority (menentukan prioritas). Setiap kriteria dan alternatif, perlu dilakaukan perbandngan berpasangan (pairwise comparison). Nilai-nilai perbandinngan relatif dariseluruh alternatif kriteri bisa disesuaikan dengan judgement yang telah ditentukan untuk menghasilan bobot dan prioritas. Bobot danprioritas dihitung dengan memanipulasi matriks atau melalui penyelesaian persamaan matematika.

3. Logical consistency (konsistensi logis). Konsistensi memiliki dua makna. Pertama, objekobjek yang serupa bisa dikelompokkan sesuai dengan keseragaman dan relevansi. Kedua, menyangkut tingkat hubungan antar objek yang didasarkan pada kriteria tertentu.

Tabel 1. Analisis Skala Perbandingan Pasangan

\begin{tabular}{|c|l|}
\hline $\begin{array}{l}\text { Intensitas } \\
\text { kepentingan }\end{array}$ & \multicolumn{1}{c|}{ Keterangan } \\
\hline $\mathbf{1}$ & Kedua elemen sama pentingnya \\
\hline $\mathbf{3}$ & Elemen yang satu sedikit lebih penting daripada elemen yang lainnya \\
\hline $\mathbf{5}$ & Elemen yang satu lebih penting daripada elemen lainnya \\
\hline $\mathbf{7}$ & Satu elemen jelas lebih mutlak penting daripada elemen lainnya \\
\hline $\mathbf{9}$ & Satu elemen mutlak penting dari pada elemen lainnya \\
\hline $\mathbf{2 , 4 , 6 , 8}$ & Nilai-nilai antara dua nilai pertimbangan yang berdekatan \\
\hline Kebalikan & $\begin{array}{l}\text { Jika aktifitas i mendapat satu } \\
\text { angka dibandingkan dengan aktifitas j, maka j memiliki nilai } \\
\text { kebalikannya dibandingkan dengan i. }\end{array}$ \\
\hline
\end{tabular}




\subsection{Hirarki Pemilihan Calon Nasabah}

Menurut Saaty, hirarki adalah gambaran dari permasalahan yang kompleks dalam struktur banyak tingkat dimana tingkat paling atas adalah tujuan dan diikuti tingkat kriteria, subkriteria dan seterusnya ke bawah sampai pada tingkat yang paling bawah adalah tingkat alternatif. Hirarki sistem ini adalah dekomposisi dari masalah pemilihan calon nasabah. Menentukan tujuan (pemilihan calon nasabah), mencari kriteria tepat yang digunakan untuk menyelesaikan tujuan serta dekomposisi dari kriteria yang telah ditentukan (Saaty 1994).

\subsection{F-AHP}

TFN dapat menunjukan subjektifik dan perbandingan berpasangan atau dapat menunjukan derajat yang pasti dari ketidakpastian. Dalam hal ini variabel linguistik dapat digunakan variabel pengambil keputusan untuk mempresentasikan ketidakpastian dengan menggunakan TFN. Variabel linguistik adalah sebuah variabel dimana nilainya berupa kata-kata atau kalimat dalam bahasa alami atau buatan. Chang mendefinisikan nilai intensitas AHP ke dalam skala fuzzy segitiga yaitu membagi tiap himpunan fuzzy dengan dua (2), kecuali untuk intensitas kepentingan satu (1). Skala fuzzy segitiga yang digunakan dapat dilihat pada Tabel 2 berikut (Chang 1996) :

Tabel 2. Analisis Skala Perbandingan Tingkat Kepentingan Fuzzy

\begin{tabular}{|c|l|c|c|}
\hline $\begin{array}{c}\text { Intensitas } \\
\text { kepentingan AHP }\end{array}$ & \multicolumn{1}{|c|}{ Himpunan Linguistik } & TFN & $\begin{array}{c}\text { Reciprocal } \\
\text { (Kebalikan) }\end{array}$ \\
\hline $\mathbf{1}$ & Perbandingan yang sama & $1,1,1$ & $1,1,1$ \\
\hline $\mathbf{2}$ & Pertengahan & $1 / 2,1,3 / 2$ & $2 / 3,1,2$ \\
\hline $\mathbf{3}$ & Elemen satu cukup penting dari yang lainnya & $1,3 / 2,2$ & $1 / 2,2 / 3,1$ \\
\hline $\mathbf{4}$ & $\begin{array}{l}\text { Pertengahan elemen satu lebih cukup } \\
\text { penting dari yang lainnya }\end{array}$ & $3 / 2,2,5 / 2$ & $2 / 5,1 / 2,2 / 3$ \\
\hline $\mathbf{5}$ & Elemen satu kuat pentingnya dari yang lain & $2,5 / 2,3$ & $1 / 3,2 / 5,1 / 2$ \\
\hline $\mathbf{6}$ & Pertengahan & $5 / 2,3,7 / 2$ & $2 / 7,1 / 3,2 / 5$ \\
\hline $\mathbf{7}$ & $\begin{array}{l}\text { Elemen satu lebih kuat pentingnya dari yang } \\
\text { lain }\end{array}$ & $3,7 / 2,4$ & $1 / 4,2 / 7,1 / 3$ \\
\hline $\mathbf{8}$ & Pertengahan & $7 / 2,4,9 / 2$ & $2 / 9,1 / 4,2 / 7$ \\
\hline $\mathbf{9}$ & $\begin{array}{l}\text { Elemen satu mutlak lebih penting dari yang } \\
\text { lainnya }\end{array}$ & $4,9 / 2,9 / 2$ & $2 / 9,2 / 9,1 / 4$ \\
\hline
\end{tabular}

\section{METODE PENELITIAN}

Tahapan yang dilalui dalam penelitian ini adalah pengumpulan data, pemodelan data, dan pengujian. Metode yang digunakan adalah metode Fuzzy Analytic Hierarchy Process (F-AHP).

\subsection{Pengumpulan Data}

Pengumpulan data yaitu melakukan observasi, mencari dan mengumpulkan data-data yang ada relevansinya dengan judul penelitian ini, seperti pengumpulan data kriteria penilaian kredit nasabah diterima dan ditolak yang memperoleh 20 data nasabah pada tahun 2011-2012 digunakan untuk mendapatkan data pengujian. Data kriteria penilaian yang ditentukan sebanyak 4 kriteria, yaitu karakter, kondisi, kapasitas, dan modal. Data dari pihak perbankan diperoleh 14 nasabah diterima dan 6 nasabah ditolak dari total 20 nasabah.

\subsection{Pemodelan Data}

Tahap pemodelan data kelayakan pemberian kredit nasabah ini dibangun dalam upaya untuk mempermudah penilaian terhadap calon nasabah yang akan mengajukan permohonan kredit. Penilaian dilakukan dengan membuat struktur hirarki yang diawali dengan tujuan umum, 
kemudian membuat matriks perbandingan berpasangan AHP dari setiap elemen terhadap masing - masing kriteria kemudian dikonversikan kedalam Triangular Fuzzy Number (TFN) pada skala fuzzy segitiga, yaitu nilai terendah (lower, dilambangkan I), tengah (median, dilambangkan $\mathrm{m}$ ), dan tertinggi (uppers, dilambangkan $\mathrm{u}$ ). Setelah di konversi ke skala fuzzy maka selanjutnya melakukan perhitungan elemen matriks synthetic pairwise comparison untuk menentukan nilai elemen matriks dari tiap kriteria yang kemudian di lanjutkan dengan menghitung rata-rata geometri fuzzy untuk memperoleh hasil bobot dari masing-masing kriteria, untuk proses perhitungan subkriteria dilakukan sama dengan menghitung kriteria matriks perbandingan berpasangan. Setelah semua penilaian tersebut diperoleh langkah terakhir yaitu menghitung total keseluruhan dari kriteria dan subkriteria dengan menggunakan data nasabah yang diperoleh dari bank BRI.

\subsection{Pengujian}

Tahap pengujian AHP dalam pengambilan keputusan mengandalkan intuisi sebagai output utamanya, namun intuisi harus datang dari pengambilan keputusan yang cukup informasi atau dianggap ahli dan memahami masalah keputusan yang dihadapi. Metode AHP mempunyai beberapa kelemahan salah satunya tidak dapat mengatasi faktor ketidakpastian yang diambil oleh pengambil keputusan ketika harus memberikan nilai yang pasti dalam matriks perbandingan berpasangan dalam mengatasi kelemahan AHP yang ada maka dikembangkan suatu metode yang disebut Fuzzy Analytic Hierarchy Process (F-AHP) yang merupakan penggabungan antara metode AHP dengan pendekatan fuzzy. Tujuan pengujian yaitu untuk mendapatkan analisa kelayakan nasabah yang diterima dan ditolak.

\section{HASIL DAN PEMBAHASAN}

\subsection{Analisis Perhitungan}

Tahapan dalam pembobotan kriteria yang dilakukan dengan metode AHP dapat dilihat sebagai berikut. Struktur hierarki dalam sistem pendukung keputusan penelitian ini dapat dilihat seperti yang ditunjukkan pada Gambar 3 dibawah ini.

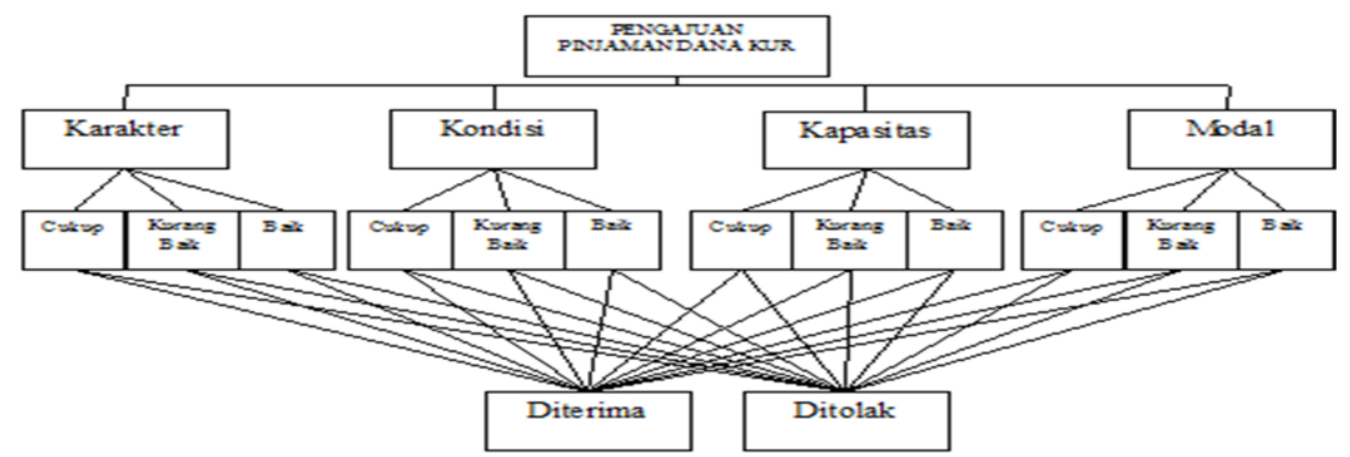

Gambar 3. Struktur Hierarki Penelitian

Berdasarkan hasil wawancara dari pihak perbankan bahwa di antara empat kriteria yang di ambil, yaitu kriteria karakter sedikit lebih penting dari pada kriteria kondisi, dan modal. Kriteria kondisi sedikit lebih penting dari pada kriteria modal. Kriteria kapasitas merupakan kriteria yang lebih penting dari pada kriteria karakter, kondisi dan modal karena bagi pihak perbankan penilaian ini dapat melihat kemampuan nasabah dala $\mathrm{m}$ mengembalikan pinjaman yang teladiberikan maka kriteria ini diprioritaskan oleh pihak perbankan. Tabel kriteria penilaian bisa dilihat di bawah ini.

Tabel 3. Kriteria Penilaian

\begin{tabular}{|c|l|c|}
\hline No. & Kriteria Penilaian & Bobot \\
\hline 1 & Karakter & $25 \%$ \\
\hline 2 & Kondisi & $17 \%$ \\
\hline 3 & Kapasitas & $46 \%$ \\
\hline 4 & Modal & $12 \%$ \\
\hline
\end{tabular}


Kemudian melakukan perhitungan AHP, yaitu dengan melakukan perbandingan dari kriteria yang telah ditentukan (karakter, kondisi, kapasitas, modal).

Tabel 4. Matriks Perbandingan Berpasangan Kriteria Pengujian Pinjaman

\begin{tabular}{|c|c|c|c|c|}
\hline Kriteria & Karakter & Kondisi & Kapasitas & Modal \\
\hline Karakter & 1 & $25 / 17$ & $25 / 46$ & $25 / 12$ \\
\hline Kondisi & $17 / 25$ & 1 & $17 / 46$ & $17 / 12$ \\
\hline Kapasitas & $46 / 25$ & $46 / 17$ & 1 & $46 / 12$ \\
\hline Modal & $12 / 25$ & $12 / 17$ & $12 / 46$ & 1 \\
\hline
\end{tabular}

Perhitungan konversi matriks perbandingan berpasangan kriteria pengujian pinjaman ke dalam skala untuk mendapatkan Total Prioritas Value (TPV) dapat dilihat pada tabel 5, tabel 6, tabel 7, dan tabel 8.

Tabel 5. Konversi Matriks Perbandingan Berpasangan Analisis Skala Kriteria Pengujian Pinjaman

\begin{tabular}{|c|c|c|c|c|}
\hline Kriteria & Karakter & Kondisi & Kapasitas & Modal \\
\hline Karakter & 1 & 2 & $1 / 2$ & 2 \\
\hline Kondisi & $1 / 2$ & 1 & $1 / 3$ & 2 \\
\hline Kapasitas & 2 & 3 & 1 & 3 \\
\hline Modal & $1 / 2$ & 1 & $1 / 3$ & 1 \\
\hline
\end{tabular}

Data di atas merupakan perhitungan yang telah dilakukan berdasarkan matriks perbandingan. Bisa dilihat pada tabel bahwa karakter sedikit lebih penting daripada kondisi dan modal. Kondisi sedikit lebih penting dari modal. Sedangkan kapasitas memiliki kriteria lebih penting dari kondisi dan modal. Tetapi kapasitas memiliki kriteria sedikit lebih penting dari karakter. Kemudian dilakukan perhitungan lagi dengan menjumlahkan kolom-kolom yang akhirnya nanti akan memperoleh nilai TPV.

Tabel 6. Jumlah Kolom Matriks Perbandingan Berpasangan

\begin{tabular}{|c|c|c|c|c|}
\hline Kriteria & Karakter & Kondisi & Kapasitas & Modal \\
\hline Karakter & 1 & 2 & 0,5 & 2 \\
\hline Kondisi & 0,5 & 1 & 0,33 & 2 \\
\hline Kapasitas & 2 & 3 & 1 & 3 \\
\hline Modal & 0,5 & 1 & 0,33 & 1 \\
\hline Zkolom & 4 & 7 & 2,16 & 8 \\
\hline
\end{tabular}

Tabel 7. Pembagian Nilai Perbandingan Dengan Jumlah Kolom

\begin{tabular}{|c|c|c|c|c|}
\hline Kriteria & Karakter & Kondisi & Kapasitas & Modal \\
\hline Karakter & $(1) /(4)$ & $(2) /(7)$ & $(0,5) /(2,16)$ & $(2) /(8)$ \\
\hline Kondisi & $(0,5) /(4)$ & $(1) /(7)$ & $(0,33) /(2,16)$ & $(2) /(8)$ \\
\hline Kapasitas & $(2) /(4)$ & $(3) /(7)$ & $(1) /(2,16)$ & $(3) /(8)$ \\
\hline Modal & $(0,5) /(4)$ & $(1) /(7)$ & $(0,33) /(2,16)$ & $(1) /(8)$ \\
\hline
\end{tabular}

Setelah diperoleh jumlah kolom dari masing-masing kriteria, maka dilanjutkan dengan membagi nilai perbandingan dengan jumlah kolom, maka akan dihasilkan nilai TPV.

Tabel 8. Pembagian Nilai Perbandingan Dengan Jumlah Kolom

\begin{tabular}{|c|c|c|c|c|c|}
\hline Kriteria & Karakter & Kondisi & Kapasitas & Modal & TPV \\
\hline Karakter & 0,25 & 0,28 & 0,23 & 0,25 & 0,25 \\
\hline Kondisi & 0,12 & 0,14 & 0,15 & 0,25 & 0,17 \\
\hline Kapasitas & 0,5 & 0,42 & 0,46 & 0,37 & 0,44 \\
\hline Modal & 0,12 & 0,14 & 0,15 & 0,12 & 0,13 \\
\hline
\end{tabular}

Oleh karena itu, TPV juga merupakan bobot dari masing-masing kriteria dalam penelitian ini, seperti yang ditunjukkan oleh tabel 9 berikut ini. 


Tabel 9. Bobot Kriteria
\begin{tabular}{|c|c|}
\hline Kriteria & Bobot \\
\hline Karakter & 0,25 \\
\hline Kondisi & 0,17 \\
\hline Kapasitas & 0,44 \\
\hline Modal & 0,13 \\
\hline
\end{tabular}

Sebelum bobot ini digunakan perlu dilakukan suatu konsistensi agar dapat mengetahui apakah kriteria dari bobot ini telah sesuai. Maka dilakukan perhitungan lagi, yaitu perkalian antara TPV dengan nilai perbandingan matriks kriteria.

Tabel 10. Perkalian TPV Dengan Nilai Perbandingan Matriks Kriteria

\begin{tabular}{|c|l|l|l|l|}
\hline Kriteria & Karakter & Kondisi & Kapasitas & \multicolumn{1}{|c|}{ Modal } \\
\hline Karakter & $1^{\star} 0,25$ & $2^{\star} 0,17$ & $1 / 2^{*} 0,44$ & $2^{\star} 0,13$ \\
\hline Kondisi & $1 / 2^{*} 0,25$ & $1^{*} 0,17$ & $1 / 3^{*} 0,44$ & $2^{*} 0,13$ \\
\hline Kapasitas & $2^{*} 0,25$ & $3^{\star} 0,17$ & $1^{\star} 0,44$ & $3^{\star} 0,13$ \\
\hline Modal & $1 / 2^{*} 0,25$ & $1^{*} 0,17$ & $1 / 3^{*} 0,44$ & $1^{*} 0,13$ \\
\hline
\end{tabular}

Setelah itu dilakukan penjumlahan entri pada matriks kriteria untuk memperoleh $\sum$ baris, seperti yang ditunjukkan oleh tabel 11 berikut ini.

Tabel 11. Penjumlahan Entri Pada Matriks Kriteria

\begin{tabular}{|c|c|c|c|c|c|}
\hline Kriteria & Karakter & Kondisi & Kapasitas & Modal & $\sum$ baris \\
\hline Karakter & 0,25 & 0,34 & 0,22 & 0,26 & 1,07 \\
\hline Kondisi & 0,12 & 0,17 & 0,14 & 0,26 & 0,69 \\
\hline Kapasitas & 0,5 & 0,51 & 0,44 & 0,39 & 1,84 \\
\hline Modal & 0,12 & 0,17 & 0,14 & 0,13 & 0,56 \\
\hline
\end{tabular}

Kemudian dilakukan perhitungan rasio konsistensi untuk membuktikan bahwa matriks yang telah dibuat diterima atau tidak. Digunakan untuk memastikan nilai $C R \leq 0,1$. jika nilai $C R \geq 0,1$ maka matriks perbandingan tidak diterima dan harus diperbaiki.

Tabel 12. Perhitungan Rasio Konsistensi

\begin{tabular}{|c|c|c|c|}
\hline Kriteria & $\sum$ baris & TPV & CR \\
\hline Karakter & 1,07 & 0,25 & 4,28 \\
\hline Kondisi & 0,69 & 0,17 & 4,05 \\
\hline Kapasitas & 1,84 & 0,44 & 4,27 \\
\hline Modal & 0,56 & 0,13 & 4,30 \\
\hline \multicolumn{4}{|c|}{ Jumlah } \\
\hline
\end{tabular}

$\lambda$ maks $=$ jumlah $/ \mathrm{n}=16,9 / 4=4,225$

$\mathrm{Cl}=(\lambda$ maks $-\mathrm{n}) /(\mathrm{n}-1)=(4,225-4) /(4-1)=0,225 / 3=0,075$

$\mathrm{CR}=\mathrm{Cl} / \mathrm{RI}=0,075 / 0,58=0,1$

Hasil perhitungan diatas menghasilkan $C R=0,1$, maka rasio konsistensi dari perhitungan tersebut bisa diterima. Dengan nilai $C R \leq 0,1$ maka bobot dalam penelitian ini terbukti konsisten dan dapat digunakan untuk menentukan kriteria penilaian mana yang lebih penting dengan acuan Tabel 1. Data di atas merupakan perhitungan yang telah dilakukan berdasarkan matriks perbandingan, seperti yang ditunjukkan oleh Tabel 12 bahwa karakter sedikit lebih penting daripada kondisi dan modal. Kondisi sedikit lebih penting dari modal. Sedangkan kapasitas memiliki kriteria lebih penting dari kondisi dan modal. Tetapi kapasitas memiliki kriteria sedikit lebih penting dari karakter. Kemudian tabel matriks perbandingan kriteria pengujian pinjaman AHP dikonversi ke dalam Tringular Fuzzy Number (TFN) berdasarkan Tabel 2 skala nilai fuzzy segitiga. Pada skala F-AHP memiliki tiga nilai, yaitu nilai terendah (lower, dilambangkan I), tengah (median, dilambangkan $\mathrm{m}$ ), dan tertinggi (uppers, dilambangkan $\mathrm{u}$ ). Berikut ini adalah hasil dari konversi matriks perbandingan AHP ke dalam matriks perbandingan kriteria pengujian pinjaman F-AHP. 
Tabel 13. Matriks Perbandingan Kriteria Pengujian Pinjaman F-AHP

\begin{tabular}{|l|c|c|c|c|c|c|c|c|c|c|c|c|}
\hline \multirow{2}{*}{ Kriteria } & \multicolumn{3}{|c|}{ Karakter } & \multicolumn{4}{c|}{ Kondisi } & \multicolumn{3}{c|}{ Kapasitas } & \multicolumn{3}{c|}{ Modal } \\
\cline { 2 - 15 } & $\boldsymbol{l}$ & $\boldsymbol{m}$ & $\boldsymbol{u}$ & $\boldsymbol{l}$ & $\boldsymbol{m}$ & $\boldsymbol{u}$ & $\boldsymbol{l}$ & $\boldsymbol{m}$ & $\boldsymbol{u}$ & $\boldsymbol{l}$ & $\boldsymbol{m}$ & $\boldsymbol{u}$ \\
\hline Karakter & 1 & 1 & 1 & $1 / 2$ & 1 & $3 / 2$ & $2 / 3$ & 1 & 2 & $1 / 2$ & 1 & $3 / 2$ \\
\hline Kondisi & $2 / 3$ & 1 & 2 & 1 & 1 & 1 & $1 / 2$ & $2 / 3$ & 1 & $1 / 2$ & 1 & $3 / 2$ \\
\hline Kapasitas & $1 / 2$ & 1 & $3 / 2$ & 1 & $3 / 2$ & 2 & 1 & 1 & 1 & 1 & $3 / 2$ & 2 \\
\hline Modal & $2 / 3$ & 1 & 2 & 1 & 1 & 1 & $1 / 3$ & $2 / 5$ & $1 / 2$ & 1 & 1 & 1 \\
\hline
\end{tabular}

Setelah konversi ke skala fuzzy dilakukan, maka selanjutnya dilakukan perhitungan elemen matriks synthetic pairwise comparison dengan rumus matematis

$$
\tilde{\mathrm{a}}_{\mathrm{ij}}=\left(\mathrm{a}_{\mathrm{ij}}^{1} \times \mathrm{a}^{2}{ }_{\mathrm{ij}} \times \ldots \times \mathrm{a}^{\mathrm{n}}{ }_{\mathrm{ij}}\right)^{1 / \mathrm{n}}
$$

dimana ãij adalah nilai elemen matriks synthetic pairwise comparison dan $\mathrm{a}^{1}{ }_{\mathrm{ij}}$ adalah nilai elemen matriks fuzzy kriteria pertama, yaitu karakter.

Tabel 14. Matriks Synthetic Pairwise Comparison

\begin{tabular}{|l|c|c|c|c|c|c|c|c|c|c|c|c|}
\hline \multirow{2}{*}{ Kriteria } & \multicolumn{3}{|c|}{ Karakter } & \multicolumn{4}{|c|}{ Kondisi } & \multicolumn{3}{c|}{ Kapasitas } & \multicolumn{3}{c|}{ Modal } \\
\cline { 2 - 15 } & $\boldsymbol{l}$ & $\boldsymbol{m}$ & $\boldsymbol{u}$ & $\boldsymbol{l}$ & $\boldsymbol{m}$ & $\boldsymbol{u}$ & $\boldsymbol{l}$ & $\boldsymbol{m}$ & $\boldsymbol{u}$ & $\boldsymbol{l}$ & $\boldsymbol{m}$ & $\boldsymbol{u}$ \\
\hline Karakter & 1 & 1 & 1 & $1 / 2$ & 1 & $3 / 2$ & $2 / 3$ & 1 & 2 & $1 / 2$ & 1 & $3 / 2$ \\
\hline Kondisi & $2 / 3$ & 1 & 2 & 1 & 1 & 1 & $1 / 2$ & $2 / 3$ & 1 & $1 / 2$ & 1 & $3 / 2$ \\
\hline Kapasitas & $1 / 2$ & 1 & $3 / 2$ & 1 & $3 / 2$ & 2 & 1 & 1 & 1 & 1 & $3 / 2$ & 2 \\
\hline Modal & $2 / 3$ & 1 & 2 & 1 & 1 & 1 & $1 / 3$ & $2 / 5$ & $1 / 2$ & 1 & 1 & 1 \\
\hline
\end{tabular}

Selanjutnya akan dilakukan perhitungan rata-rata geometri fuzzy dengan rumus matematis sebagai berikut:

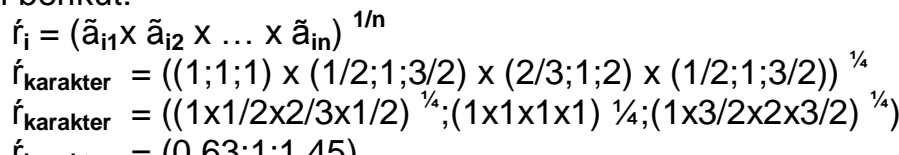

$\dot{r}_{\text {karakter }}=(0,63 ; 1 ; 1,45)$

Dari contoh perhitungan maka nilai rata-rata geometri fuzzy dari setiap kelompok:

$\dot{r}_{\text {karakter }}=(0,63 ; 1 ; 1,45)$

$\dot{r}_{\text {kondisi }}=(0,63 ; 0,90 ; 1,31)$

$\dot{r}_{\text {kapasitas }}=(0,84 ; 1,22 ; 1,56)$

$\dot{r}_{\text {modal }}=(0,68 ; 0,79 ; 1)$

Setelah mendapatkan nilai rata-rata geometri fuzzy dilakukan perhitungan nilai bobot dari masing-masing kriteria

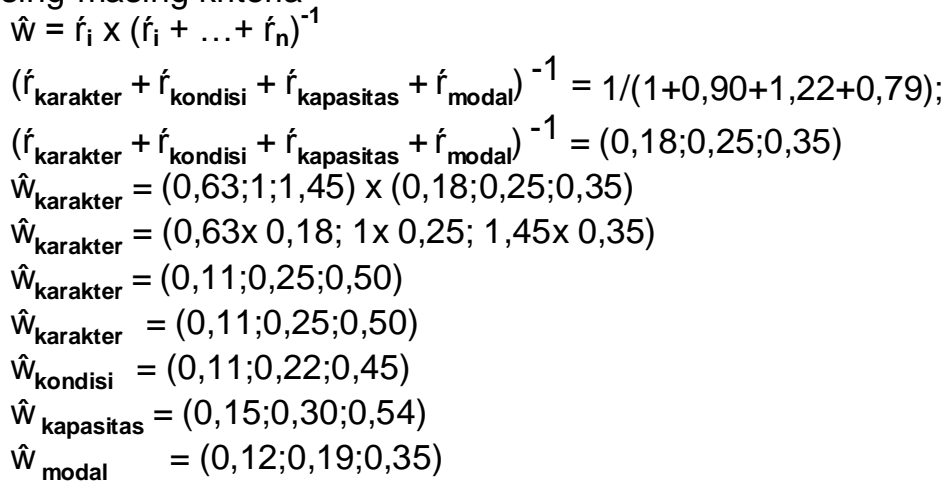

Setelah rasio konsistensi pada kriteria diterima maka dilakukan perhitungan pada sub kriteria dengan proses yang tidak jauh berbeda dengan proses di atas. 
Tabel 15 Matriks Perbandingan Berpasangan Subkriteria Karakter

\begin{tabular}{|c|c|c|c|}
\hline Subkriteria & Kurang & Cukup Baik & Baik \\
\hline Kurang & 1 & 0,33 & 0,20 \\
\hline Cukup Baik & 3 & 1 & 0,33 \\
\hline Baik & 5 & 3 & 1 \\
\hline ¿kolom & 9 & 4,33 & 1,53 \\
\hline
\end{tabular}

Perhitungan dilakukan pertama-tama pada kriteria karakter. Matriks nilai kriteria karakter dapat dilihat pada Tabel 16 berikut ini:

Tabel 16 Matriks Nilai Subkriteria Karakter

\begin{tabular}{|c|c|c|c|c|c|}
\hline Subkriteria & Kurang & Cukup Baik & Baik & $\sum$ kolom & TPV \\
\hline Kurang & 0,11 & 0,07 & 0,13 & 0,31 & 0,10 \\
\hline Cukup Baik & 0,33 & 0,23 & 0,21 & 0,78 & 0,26 \\
\hline Baik & 0,56 & 0,69 & 0,65 & 1,92 & 0,64 \\
\hline
\end{tabular}

Tabel 17 Bobot Subkriteria Karakter

\begin{tabular}{|c|c|}
\hline Subkriteria & Bobot \\
\hline Kurang & 0,10 \\
\hline Cukup Baik & 0,26 \\
\hline Baik & 0,64 \\
\hline
\end{tabular}

Sebelum bobot ini digunakan perlu dilakukan suatu konsistensi agar dapat mengetahui apakah subkriteria dari bobot ini telah sesuai. Maka dilakukan perhitungan lagi yaitu perkalian antara TPV dengan nilai perbandingan matriks subkriteria.

Tabel 18 Perkalian TPV Dengan Nilai Perbandingan Matriks Subkriteria Karakter

\begin{tabular}{|c|c|c|c|}
\hline Subkriteria & Kurang & Cukup Baik & Baik \\
\hline Kurang & $1^{\star} 0,10$ & $0,33^{\star} 0,26$ & $0,20^{\star} 0,64$ \\
\hline Cukup Baik & $3^{\star} 0,10$ & $1^{\star} 0,26$ & $0,33^{\star} 0,64$ \\
\hline Baik & $5^{\star} 0,10$ & $3^{\star} 0,26$ & $1^{\star} 0,64$ \\
\hline
\end{tabular}

Setelah itu dilakukan penjumlahan entri pada matriks kriteria untuk memperoleh $\sum$ baris. Hasil dapat dilihat pada Tabel 19 berikut ini.

Tabel 19 Perkalian TPV Dengan Nilai Perbandingan Matriks Subkriteria Karakter

\begin{tabular}{|c|c|c|c|c|}
\hline Subkriteria & Kurang & Cukup Baik & Baik & $\sum$ baris \\
\hline Kurang & 0,10 & 0,09 & 0,13 & 0,32 \\
\hline Cukup Baik & 0,30 & 0,26 & 0,21 & 0,77 \\
\hline Baik & 0,50 & 0,78 & 0,64 & 1,92 \\
\hline
\end{tabular}

Kemudian dilakukan perhitungan rasio konsistensi untuk membuktikan bahwa matriks yang telah dibuat diterima atau tidak. Digunakan untuk memastikan nilai $\mathrm{CR} \leq 0.1$. jika nilai $\mathrm{CR}$ $\geq 0.1$ maka matriks perbandingan tidak diterima dan harus diperbaiki.

Tabel 20 Perhitungan Rasio Konsistensi Subkriteria Karakter

\begin{tabular}{|c|c|c|c|}
\hline Subkriteria & $\sum$ baris & TPV & CR \\
\hline Kurang & 0,32 & 0,10 & 3,2 \\
\hline Cukup Baik & 0,77 & 0,26 & 2,96 \\
\hline Baik & 1,92 & 0,64 & 3 \\
\hline \multicolumn{3}{|c|}{ Jumlah } & 9,16 \\
\hline
\end{tabular}

$\lambda$ maks $=$ jumlah $/ \mathrm{n}=9,16 / 3=3,05$

$\mathrm{Cl}=(\lambda$ maks $-\mathrm{n}) /(\mathrm{n}-1)=(3,05-3) /(3-1)=0,05 / 2=0,025$

$\mathrm{CR}=\mathrm{Cl} / \mathrm{RI}=0,025 / 0,58=0,04$ 
Dari perhitungan diatas menghasilkan nilai $\mathrm{CR}=0,04$, maka rasio konsistensi dari perhitungan tersebut bisa diterima. Dengan nilai $C R \leq 0,1$ maka bobot dalam penelitian ini terbukti konsisten dan dapat digunakan untuk menentukan kriteria penilaian mana yang lebih penting dengan acuan Tabel 1. Selanjutnya dilakukan konversi ke dalam Triangular Fuzzy Number (TFN).

Tabel 21 Matriks Perbandingan Berpasangan Subkriteria Karakter F-AHP

\begin{tabular}{|l|c|c|c|c|c|c|c|c|c|}
\hline \multirow{2}{*}{ Subkriteria } & \multicolumn{3}{|c|}{ Kurang } & \multicolumn{3}{c|}{ Cukup Baik } & \multicolumn{3}{c|}{ Baik } \\
\cline { 2 - 11 } & $l$ & $m$ & $u$ & $l$ & $m$ & $u$ & $l$ & $m$ & $u$ \\
\hline Kurang & 1 & 1 & 1 & $1 / 2$ & $2 / 3$ & 1 & $1 / 3$ & $2 / 5$ & $1 / 2$ \\
\hline Cukup Baik & 1 & $3 / 2$ & 2 & 1 & 1 & 1 & $1 / 2$ & $2 / 3$ & 1 \\
\hline Baik & 2 & $5 / 2$ & 3 & 1 & $3 / 2$ & 2 & 1 & 1 & 1 \\
\hline
\end{tabular}

Setelah konversi ke skala fuzzy dilakukan, maka selanjutnya dilakukan perhitungan elemen matriks synthetic pairwise comparison.

Tabel 22 Matriks Synthetic Pairwise Comparison Subkriteria Karakter

\begin{tabular}{|l|c|c|c|c|c|c|c|c|c|}
\hline \multirow{2}{*}{ Subkriteria } & \multicolumn{3}{|c|}{ Kurang } & \multicolumn{3}{c|}{ Cukup Baik } & \multicolumn{3}{c|}{ Baik } \\
\cline { 2 - 11 } & $l$ & $m$ & $u$ & $l$ & $m$ & $u$ & $l$ & $m$ & $u$ \\
\hline Kurang & 1 & 1 & 1 & $1 / 2$ & $2 / 3$ & 1 & $1 / 3$ & $2 / 5$ & $1 / 2$ \\
\hline Cukup Baik & 1 & $3 / 2$ & 2 & 1 & 1 & 1 & $1 / 2$ & $2 / 3$ & 1 \\
\hline Baik & 2 & $5 / 2$ & 3 & 1 & $3 / 2$ & 2 & 1 & 1 & 1 \\
\hline
\end{tabular}

Selanjutnya dilakukan perhitungan rata-rata geometris

$$
\begin{aligned}
& \dot{r}_{i}=\left(\tilde{a}_{i 1} \times \tilde{a}_{i 2} \times \ldots \times \tilde{a}_{\text {in }}\right) \\
& \dot{r}_{\text {kurang }}=(0,55 ; 0,64 ; 0,79) \\
& \dot{r}_{\text {cukup baik }}=(0,79 ; 1 ; 1,25) \\
& \dot{r}_{\text {baik }}=(1,25 ; 1,55 ; 1,81)
\end{aligned}
$$

selanjutnya dilakukan perhitungan untuk mengetahui bobot fuzzy dari tiap subkriteria karakter

$$
\begin{aligned}
& \hat{W}=\dot{r}_{i} \times\left(\dot{r}_{i}+\ldots+\dot{r}_{n}\right)^{-1} \\
& \left(\hat{r}_{\text {kurang }}+\dot{r}_{\text {cukup baik }}+\dot{r}_{\text {baik }}\right)^{-1}=(0,25 ; 0,31 ; 0,38) \\
& \hat{W}_{\text {kurang }}=(0,13 ; 0,19 ; 0,30)
\end{aligned}
$$$$
\hat{\mathrm{w}}_{\text {cukup baik }}=(0,19 ; 0,31 ; 0,47)
$$$$
\hat{\mathrm{W}}_{\text {baik }}=(0,31 ; 0,48 ; 0,68)
$$

Langkah selanjutnya adalah membuat perhitungan nilai BNP (Best Non-Fuzzy Performance). BNP adalah salah satu metode yang digunakan dalam proses defuzzikasi. Defuzzifikasi adalah langkah terakhir dalam suatu sistem logika fuzzy dimana tujuannya adalah mengkonversi setiap hasil dari inference engine yang diekspresikan dalam bentuk fuzzy set kesuatu bilangan real. Rumusnya BNP adalah sebagai berikut:

$$
\begin{array}{ll}
\mathrm{BNP} i & =\left[\left(u R_{i}-I R_{i}\right)+\left(m R_{i}-I R_{i}\right)\right] / 3+I R_{i} \\
\hat{\text { Wkarakter }} & =(0,11 ; 0,25 ; 0,50)
\end{array}
$$$$
\text { BNPkarakter }=[(0,50-0,11)+(0,25-0,11)] / 3+0,11
$$$$
\text { BNPkarakter }=[(0,39+0,14)] / 3+0,11
$$

$\mathrm{BNP}_{\text {karakter }}=0,28$

Dari contoh perhitungan tersebut, maka nilai BNP dari masing-masing kriteria adalah

$\mathrm{BNP}_{\text {karakter }}=0,28$

BNP kondisi $=0,26$

BNPkapasitas $=0,33$

$\mathrm{BNP}_{\text {modal }}=0,22$

BNP untuk subkriteria diambil dari bobot keseluruhan dari subkriteria tersebut. Dimana bobot keseluruh dari subkriteria tersebut didapat dari hasil perkalian nilai bobot subkriteria dengan bobot super kriterianya. Bobot keseluruhan subkriteria kurang

$=$ Ŵkarakter $\times$ ŵkurang

$=(0,11 ; 0,25 ; 0,50) \times(0,13 ; 0,19 ; 0,30)$

$=0,01 ; 0,04 ; 0,15$

Berikut adalah hasil perhitungan BNP dari seluruh kriteria dan subkriteria: 
Tabel 23 Hasil Perhitungan BNP Dari Seluruh Kriteria Dan Subkriteria

\begin{tabular}{|l|l|c|c|c|c|c|c|c|}
\hline \multicolumn{2}{|c|}{ Kriteria/Subkriteria } & \multicolumn{3}{|c|}{ Bobot Lokal } & \multicolumn{3}{c|}{ Bobot Keseluruhan } & BNP \\
\hline Karakter & & 0,11 & 0,25 & 0,50 & & & & 0,28 \\
\hline \multirow{5}{*}{} & Kurang & 0,13 & 0,19 & 0,31 & 0,01 & 0,04 & 0,15 & 0,20 \\
\cline { 2 - 9 } & Cukup Baik & 0,19 & 0,31 & 0,48 & 0,02 & 0,07 & 0,23 & 0,32 \\
\cline { 2 - 9 } & Baik & 0,30 & 0,47 & 0,68 & 0,03 & 0,12 & 0,34 & 0,49 \\
\hline Kondisi & & 0,11 & 0,22 & 0,45 & & & & 0,26 \\
\hline \multirow{5}{*}{ Kapasitas } & Kurang & 0,13 & 0,19 & 0,31 & 0,01 & 0,04 & 0,13 & 0,20 \\
\cline { 2 - 9 } & Cukup Baik & 0,19 & 0,31 & 0,48 & 0,02 & 0,06 & 0,21 & 0,32 \\
\cline { 2 - 9 } & Baik & 0,30 & 0,47 & 0,68 & 0,03 & 0,10 & 0,30 & 0,49 \\
\hline \multirow{5}{*}{ Modal } & 0,15 & 0,30 & 0,54 & & & & 0,33 \\
\hline \multirow{5}{*}{} & Kurang & 0,13 & 0,19 & 0,31 & 0,01 & 0,05 & 0,16 & 0,20 \\
\cline { 2 - 9 } & Cukup Baik & 0,19 & 0,31 & 0,48 & 0,02 & 0,09 & 0,25 & 0,32 \\
\cline { 2 - 9 } & Baik & 0,30 & 0,47 & 0,68 & 0,04 & 0,14 & 0,36 & 0,49 \\
\hline & & 0,12 & 0,19 & 0,35 & & & & 0,22 \\
\cline { 2 - 9 } & Kukup Baik & 0,13 & 0,19 & 0,31 & 0,01 & 0,03 & 0,10 & 0,20 \\
\cline { 2 - 9 } & Baik & 0,30 & 0,41 & 0,48 & 0,02 & 0,05 & 0,16 & 0,32 \\
\hline
\end{tabular}

\subsection{Hasil Pengujian}

Berdasarkan hasil seleksi pengujian terhadap 20 data nasabah bank BRI diperoleh 14 nasabah diterima dan 6 nasabah ditolak. Hasil dari 14 nasabah yang diterima tersebut memiliki nilai diatas 50. Sedangkan 6 nasabah ditolak karena memiliki nilai dibawah 50. Kedinamisan dari nilai bobot ini yang dijadikan dasar sebagai nilai prioritas nasabah yang dapat direkomendasikan untuk mendapatkan kredit atau tidak mendapatkan kredit. Presentase tingkat kevalidasian dari uji program yang telah dilakukan di Bank Rakyat Indonesia Unit Tempel adalah $100 \%$ sama dengan perolehan pihak perbankan. Perbandingan hasil seleksi bank dengan metode FAHP dapat dilihat pada Tabel 24 berikut ini.

Tabel 24 Perbandingan Hasil Seleksi Bank Dengan Hasil Uji Metode F-AHP

\begin{tabular}{|c|l|l|l|}
\hline No & Nama Nasabah & Hasil Seleksi Bank & \multicolumn{1}{|c|}{ Hasil Seleksi Sistem } \\
\hline 1 & Hardiyanto & diterima & diterima \\
\hline 2 & Wardayati & diterima & diterima \\
\hline 3 & Didik Budi Prastowo & diterima & diterima \\
\hline 4 & Setia Rahayu & diterima & diterima \\
\hline 5 & Dhonny Prasetyo & diterima & diterima \\
\hline 6 & Aris Noor Rahman & diterima & diterima \\
\hline 7 & Sri Rusnawati & diterima & diterima \\
\hline 8 & Arif Andriawan & diterima & diterima \\
\hline 9 & Atik Wulandari & diterima & diterima \\
\hline 10 & Suharni & diterima & diterima \\
\hline 11 & Tri Supiyatun & diterima & diterima \\
\hline 12 & Santoso & diterima & diterima \\
\hline 13 & Agung Riyadi & diterima & diterima \\
\hline 14 & Nuradi & diterima & diterima \\
\hline 15 & Sumirah & ditolak & ditolak \\
\hline 16 & Irawan & ditolak & ditolak \\
\hline 17 & Primadini & ditolak & ditolak \\
\hline 18 & Danar Pratomo & ditolak & ditolak \\
\hline 19 & Tias Astuti & ditolak & ditolak \\
\hline 20 & Fathur & ditolak & ditolak \\
\hline & & & \\
\hline
\end{tabular}




\section{PENUTUP}

\subsection{Kesimpulan}

Sistem Pendukung Keputusan (SPK) pemilihan nasabah menggunakan metode F-AHP telah berhasil dibangun untuk menghasilkan keputusan berupa daftar perangkingan calon nasabah yang berhak memperoleh dana KUR. Kelayakan nasabah dinilai berdasarkan karakter, kapasitas, modal, dan kondisi ekonomi. Kriteria karakter memiliki variabel sedikit lebih penting dari pada kriteria kondisi dan modal dengan masing-masing nilai bobot $0,28,0,26$, dan 0,22. Kriteria kondisi memiliki variabel sedikit lebih penting dari pada kriteria modal dengan masingmasing nilai bobot 0,26 dan 0,22 . Kriteria kapasitas memiliki variabel lebih penting dari pada kriteria karakter, kondisi dan modal dengan masing - masing bobot 0,33, 0,28, 0,26, dan 0,22. Dari hasil pengujian menggunakan metode F-AHP menghasilkan 14 kriteria nasabah diterima dan 6 kriteria nasabah ditolak dengan total 20 nasabah yang mempunyai akurasi $100 \%$ hasil sama dengan pihak bank.

\subsection{Saran}

Saran untuk penelitian selanjutnya adalah dapat mengembangkan keputusan kelayakan pemberian kredit nasabah dengan penambahan kompleksitas kriteria (jaminan) yang diberikan sesuai kebijakan masing-masing bank untuk dapat menganalisa dan membahas kebijakan yang akan diambil oleh pihak perbankan dalam menentukan kelayakan pemberian kredit kepada calon nasabah dengan lebih tepat dan akurat.

\section{DAFTAR PUSTAKA}

Chang, D,Y.1996. Application of The Extent Analysis Method on AHP, European Journal of Operational Research 95:649-655.

Kusumadewi, S. dan Purnomo, H. 2010, Aplikasi Logika Fuzzy untuk Pendukung Keputusan, Edisi 2, Penerbit Graha IImu, Yogyakarta, 1-29.

Ozdagoglu, A. and Ozdagoglu, G. 2007, Comparison of AHP and Fuzzy AHP for The Multicriteria Decision Making Process With Linguistic Evaluations, Journal of IstambulTicaret Universities (6), 65-85.

Pato, S. 2013. Analisis Pemberian Kredit Mikro Pada Bank Syariah Mandiri Cabang Manado, Jurnal EMBA Vol.1 No.4, Desember 2013, Hal. 875-885.

Saaty, T.L. (1990). Multicriteria decision making: the analytic hierarchy process: planning, priority setting resource allocation (2nd ed.). Pittsburgh, PA: RWS Publications.

Saaty, T.L. and Vargas, L.G. (1991) Prediction, Projection and Forecasting, Boston: Kluwer

Saaty, T.L. (1994) How to make a decision: the analytic hierarchy process, Interfaces, Vol. 24, No. 6, pp.19-43.

Saaty, T.L. (2008) Decision making with the analytic hierarchy process, Int. J. Services Sciences, Vol. 1, No. 1, pp.83-98.

Vahidnia, M.H. 2008. Fuzzy Analytical Hierarchy Process in GIS Application, Journal ofThe International Archives of the Photogrammetry Remote Sensing and Spatial Information SciencesFaculty of Geodesy and Geomatics Eng. K.N.Toosi University of Technology (37), 593-596. 